\title{
The major interest for crop protection of agrochemical substances without maximum residue limit (MRL)
}

\author{
Mathilde Charon, Diane Robin, Patrice A. Marchand \\ Institut Technique de l'Agriculture Biologique (ITAB), Inputs Dept. Paris (France).E-mail: patrice.marchand@itab.asso.fr
}

Received on 29 May 2018, accepted on 23 January 2019, available online 4 February 2019.

This article is distributed under the terms and conditions of the CC-BY License (http://creativecommons.org/licenses/by/4.0)

Description of the subject. The real-time management of residues of plant protection products is a general issue for food producers and/or exporters. Authorized pesticides under European Regulation (EC) No 1107/2009 (Reg. 1107/2009) are granted a maximum residue limit (MRL) defined by the European Chemicals Agency (ECHA). These maximum residue limits are managed by the European Commission and listed in EC Regulation No 396/2005. MRLs for newly approved substances are set for pesticide residues present in products or groups of products covered by Annex I with a default value of $0.01 \mathrm{mg}$. $\mathrm{kg}^{-1}$, unless they have been considered, elaborated upon on approval and affected in one of the six other Annexes (II to VII). Substances listed in Annex IV are favoured in the selection of substances to be used by producers as it is for substances with very low potential impacts (low-risk substances [Art. 22 of Reg. 1107/2009] which therefore require no MRL; basic substances [Art. 23 of Reg. 1107/2009]; and microorganisms). The number of substances affected by this lack of an MRL (without residues survey requirement) has been steadily increasing since the publication of the SANCO/11188/2013 Guideline. Many biocontrol agents are listed in Annex IV, including microbial insecticides (e.g. Bacillus thuringiensis, Cydia pomonella granulosis virus), semiochemicals used in traps (e.g. ammonium acetate, putrescine) and some natural substances (e.g. sulphur) as well as all the currently listed basic substances.

Objectives. To show that plant protection may be achieved with less concern or control (auto + external) than with certain agrochemical pesticides, including those without maximum residue limits (MRL).

Method. Analysis of EU Pesticide Database and EU Regulation (EU) No 540/2011.

Results. All approved pesticide active substances with no MRL included in Annex IV of Regulation (EC) No 396/2005, listed by substance status type (active, low-risk or basic) and category (microorganism, semiochemical or natural).

Conclusions. These results may be used to help achieve plant protection with much less risk of contaminations, while noting the necessity for controls, analytical issues, positive controls, as well as the possibility of downgrading and withdrawal of approval from the market.

Keywords. Maximum residue limits (MRL), basic substances, low-risk substances, plant protection, Regulation (EC) No 396/2005.

Intérêt majeur des substances actives en protection des cultures sans limite maximale de résidu (LMR)

Description du sujet. La gestion quotidienne des résidus de produits phytosanitaires est un problème général pour les producteurs et/ou les exportateurs de denrées alimentaires. Les pesticides autorisés par le règlement phytosanitaire européen CE No 1107/2009 (RCE No 1107/2009) sont affectés d'une limite maximale de résidus (LMR) définies par l'Agence Européenne des produits chimiques (ECHA). Cette LMR est gérée par la Commission européenne et déclinée dans le Règlement (CE) No 396/2005. Les LMR des substances nouvellement approuvées sont fixées dans les produits ou groupes de produits visés à l'Annexe I avec une valeur par défaut de $0,01 \mathrm{mg} \cdot \mathrm{kg}^{-1}$ (sauf si elles ont été considérées et calculées lors de l'approbation et affectées dans l'une des six autres Annexes [II à VII]). L'utilisation des substances contenues dans l'annexe IV est à privilégier par les producteurs : en effet, elle confère une absence de LMR pour des substances à très faibles impacts potentiels (substances à faibles risques [Art. 22 du RCE 1107/2009], substances de base [Art. 23 du RCE 1107/2009], micro-organismes). Le nombre de substances affectées par cette absence de LMR et donc l'absence de recherche de résidus, est en constante augmentation depuis la publication du Guideline SANCO/11188/2013. Les catégories et les substances correspondantes placées dans l'annexe IV sont présentées : de nombreux agents de biocontrôle comme les micro-organismes insecticides (Bacillus thuringiensis, virus de la granulose de Cydia pomonella), de nombreux médiateurs chimiques utilisés dans les pièges (acétate d'ammonium, putrescine) et certaines substances naturelles (soufre), ainsi que toutes les substances de base actuelles. 
Objectifs. Ces résultats peuvent être utilisés pour montrer que la protection des plantes peut être effectuée avec plus de prévention des contaminations, moins de crainte de résidus, de nécessité de contrôle, de besoin de contrôles et de problèmes analytiques, de contrôles positifs, de déclassement et de retrait du marché en utilisant certains types de pesticides, ceux sans LMR.

Méthode. Une analyse de la base de données de pesticides de l'UE et du Règlement (UE) No 540/2011.

Résultats. Toutes les substances actives pesticides approuvées sans LMR (inclus dans l'annexe IV du Règlement [CE] No 396/2005) listées par type de statut (active, faible risque ou de base) et catégorie (micro-organisme, médiateur chimique ou naturel).

Conclusions. Ces résultats peuvent être utilisés pour la protection des plantes afin d'éviter les contaminations, contrôles positifs, problèmes analytiques, les déclassements ou les retraits du marché.

Mots-clés. Limite Maximale de Résidus (LMR), substances de base, substances à faibles risques, protection des plantes, Règlement (CE) No 396/2005.

\section{INTRODUCTION}

The management of residues from plant protection products in real-time is a general issue for crop and food producers, exporters and end users alike (food process industry, consumers), as well as the health concerns of the general population, especially as regards baby food (Yamada, 2017). The Maximum Residue Limits (MRL) of any active substance is of importance at the international level for different reasons including legal requirements (Villaverde et al., 2016), and trade barriers (Xiong \& Beghin, 2014; Yeung et al.,2017).Establishing MRLs increases costs due to the requirement for sampling (Fleming et al., 2017), establishing analytical methods (Romero-González, 2015) and subsequent routine analyses (De Brabander et al., 2011). But, at the same time, the demand for pesticide survey and monitoring is increasing (Pedersen et al., 2016). Although these steps are compulsory (Villaverde et al., 2016) the global cost for legal compliance is quite high and the labour required depends upon the value of the limit of quantification required.

Currently, analysis of pesticide residues is an important concern for complying with pesticide regulations. The limit of quantification (LOQ) set for residue analysis is closely related to the Maximum Residue Limit (MRL) of the surveyed substance for the corresponding crop. MRLs of any active substance are not dependant on the applicant's choice but are settled, defined and harmonized by the European Chemicals Agency (ECHA) and listed in one Annex (II to VII) of Regulation (EC) No 396/2005 (EC, 2005); Annex I, recently updated (EU, 2018a), includes the definition of product parts. After approval, substances are assigned to one of the five parts (A, B, C, D and E) of Implementing Regulation (EC) No 540/2011 (EU, 2011) with all MRLs of substances exhibiting a positive value (in $\mathrm{mg} \cdot \mathrm{kg}^{-1}$ or ppm) being listed in Annexes II to VII of the Regulation (EC) No 396/2005; except the substances listed in Annex IV. Most MRLs for newly approved substances under EU pesticides Regulation (EC) No 1107/2009 (EC, 2009a) are set for the pesticide residues present in products or groups of products covered by Annex I of Regulation (EC) No 396/2005 with a default value of $0.01 \mathrm{mg} \cdot \mathrm{kg}^{-1}$ (unless they have been taken into account, elaborated upon approval and assigned in one of Annexes II to VII). The substances listed in Annex IV have no MRL and so the absence of Maximum Residue Limits is exclusively for substances with very low potential impacts. Therefore, these substances are likely to be favoured in the selection of substances used by producers because there is no need for residue surveys. This is certainly the case for certifiers of new brands of all kinds claiming to produce food stuffs "without pesticide residues".

\section{MATERIALS AND METHODS}

\subsection{Materials}

EU Pesticide Database. The EU pesticide database (DGSanté, 2017a) is an updated online database of all active substances depending on the EU pesticides Regulation (EC) No 1107/2009 (EC, 2009a) whether approved or not, and listed in Implementing Regulation (EC) No 540/2011 (EU, 2011).

European regulations. A consolidated version of Regulation (EC) No 396/2005 with all modifications and updates may be found via EUR-Lex (EC, 2005). A consolidated version of Implementing Regulation (EC) No 540/2011 is also useful for checking all changes in the approval/renewal/withdrawal process.

\subsection{Methodology: database search}

The EU pesticide database may be searched in diverse ways, such as by substance type (DGSanté, 2017a; DGSanté, 2017b) for basic and low-risk substances. MRLs for all active substances in corresponding crops are detailed but no search can be performed with MRL values or location in the corresponding Annexes of Regulation (EC) No 396/2005; therefore a manual 
search is required. Thus, up until now, no automatic search could be undertaken on the EU pesticides database with the "advance search" process. However, full MRLs values in XML format may be downloaded from the website.

\section{RESULTS}

\subsection{Pesticide types or categories}

Applications for substances with very low potential impacts (toxicity or environmental toxicity) such as low-risk substances (Article 22 of Regulation 1107/2009), basic substances (Article 23 of Regulation $1107 / 2009$ ), or microorganisms, are likely to be granted with an absence of MRLs. The number of substances affected by this lack of MRLs (i.e. without a residue survey requirement) has been steadily increasing since the publication of the SANCO/11188/2013 Guideline (DGSanté, 2015). Many biocontrol agents are listed in Annex IV including microbial insecticides (e.g. Bacillus thuringiensis, Cydia pomonella granulosis virus), semiochemicals used in traps (e.g. ammonium acetate, putrescine) and some natural substances (e.g. sulphur), as well as all current basic substances.

Basic substances. Our previous work has shown that up to now all basic substances were approved with no MRLs (Marchand, 2015; Marchand, 2016; Marchand, 2017a). Thus, all approved "basic substances" up to now were assigned to Annex IV (no MRL) of Regulation (EC) No 396/2005 a few months after approval (DGSanté, 2015). Hydrogen peroxide was assimilated in this study to "natural substance" due to its natural occurrence as primary wound signalling molecule. Since 2018, the Residues Standing Committee has been looking to set MRLs for non-approved basic substances (11 substances).

Low-risk substances. Low-risk substances (i.e. microorganisms) usually show specific and/or very particular physical and chemical characteristics that can make the required analysis difficult. A similar issue regarding MRLs was observed with the previously approved low-risk substances (Marchand, 2017b; Marchand, 2018a; Robin \& Marchand, 2019), as detailed in the specific guidance document on inclusion in the same Annex IV (DGSanté, 2015) as basic substances; although this may not be the case for all subsequent low-risk substances.

\subsection{Maximum Residue Limits survey}

Other than the basic and low-risk categories, the search for substances with no MRL needs to be performed manually through the EU Pesticides Database (DGSanté, 2017c). To update these tables, a consolidated version of Implementing Regulation (EC) No 396/2005 is also useful to track all changes in the MRLs and to notice the recent changes in Annex IV.

\subsection{Outputs}

Information provided in each table is listed by substance name in alphabetical order, together with its status; active (a.s.), basic (b.s.) and low-risk substance (1-r.s.). Lists of substances without MRL are provided here: biocontrol agents such as microorganisms (virus, bacteria and fungus) are listed in table 1, semiochemicals (pheromones and allelochemicals) are listed in table 2 and natural substances from mineral, animal, microbial plant or biological origin are listed in table 3. This biocontrol classification was defined by earlier work with its repartition into sub-classes fully described (Robin \& Marchand, 2018). Distribution of the substance categories and types are displayed in figures 1 and 2.

\subsection{Regular monitoring}

Although no automatic search may be undertaken on the EU pesticides database, tracking MRLs can be anticipated by analysing the agenda of the Phytopharmaceuticals - Pesticides Residues Standing Committee of the Plants, Animals, Food and Feed Standing Committee (PAFF). Moreover, the summaries of these meetings may help users to follow the MRL settings. This information will appear in later corresponding Implementing Regulations with a six to eight weeks delay.

\section{DISCUSSION}

Among all the crop protection substances listed in Annex IV with no MRL (120 substances), most of them are considered as biocontrol agents (BCA), such as volatile semiochemicals, microorganisms and natural substances. The remainder are small molecules and

Table 2. Approved substances under Regulation 1107/2009 as semiochemicals - Médiateurs chimiques approuvés par le Règlement 1107/2009.

\begin{tabular}{ll}
\hline Name & Category \\
\hline 1-dodecanol & active substance \\
Ammonium acetate & active substance \\
Di Ammonium Phosphate (DAP) & basic substance \\
Trimethylamine hydrochloride & active substance \\
\hline
\end{tabular}


Table 1.Approved substances under Reg. 1107/2009 as microorganisms - Micro-organismes approuvés par le Reg.1107/2009.

Name

Adoxophyes orana granulovirus strain BV-0001

Ampelomyces quisqualis AQ10

Aureobasidium pullulans strains DSM 14941 and DSM 14940

Bacillus amyloliquefaciens subsp. plantarum D747

Bacillus amyloliquefaciens FZB24

Bacillus amyloliquefaciens MBI 600

Bacillus firmus 1-1582

Bacillus pumilus strain QST 2808

Bacillus subtilis QST 713

Bacillus thuringiensis subsp. aizawai strains ABTS-1857 and GC-91

Bacillus thuringiensis sp. kurstaki strains ABTS 351, PB 54, SA 11, SA12 and EG 2348

Bacillus thuringiensis var. tenebrionis strain NB 176 (TM 14 1)

Beauveria bassiana strains ATCC 74040 and GHA

Candida oleofila strain $\mathrm{O}$

Coniothyrium minitans

Cydia pomonella granulovirus (CpGV)

Gliocladium catenulatum strain J 1446

Isaria fumosorosea Apopka strain 97 (aka) Paecilomyces fumosoroseus strain Apopka 97

Metschnikowia fructicola strain NRRL Y-27328

Mild Pepino Mosaic Virus isolate VC 1

Mild Pepino Mosaic Virus isolate VX 1

Lecanicillium muscarium strain Ve6

Metarhizium anisopliae var. anisopliae strain BIPESCO 5/F52

Helicoverpa armigera nucleopolyhedrovirus (HearNPV)

Pasteuria nishizawae Pn1

Pepino Mosaic Virus strain CH2 isolate 1906

Phlebiopsis gigantea (several strains)

Pseudomonas chlororaphis strain MA 342

Pvthium oligandrum strain M1

Saccharomyces cerevisiae LAS02

Spodoptera littoralis nucleopolyhedrovirus

Streptomyces K61 (formerly S. griseoviridis)

Trichoderma asperellum (formerly T. harzianum) strains ICC012, T25 and TV1

Trichoderma asperellum (strain T34)

Trichoderma atroviride strain I-1237

Trichoderma atroviride strain SC1

Trichoderma gamsii (formerly T. viride) strain ICC080

Trichoderma harzianum (formerly T. harzianum) strains IMI 206040 and T11

Trichoderma harzianum strains T-22 and ITEM 908

Trichoderma polysporum strain IMI 206039

Lecanicillium muscarium (formerly Verticillium lecanii) strain Ve6

Verticillium albo-atrum ((formerly Verticillium dahliae) strain WCS850

Zucchini Yellow Mosaic Virus, weak strain

\section{Category}

active substance

low risk-substance active substance

active substance low risk-substance active substance active substance active substance active substance active substance active substance active substance active substance active substance low risk-substance active substance active substance low risk-substance active substance low risk-substance low risk-substance active substance active substance active substance low risk-substance low risk-substance active substance active substance active substance low risk-substance active substance active substance active substance active substance active substance low risk-substance active substance active substance active substance active substance active substance active substance active substance 
Table 3. Approved natural substances under Regulation 1107/2009 - Substances naturelles approuvées par le Règlement 1107/2009.

\begin{tabular}{|c|c|}
\hline Name & Category \\
\hline S-Abscisic acid & a.s. \\
\hline Aluminium silicate (aka kaolin) & a.s. \\
\hline Beer & b.s. \\
\hline 6-Benzyladenine & a.s. \\
\hline Benzoic acid & a.s. \\
\hline Blood meal & a.s. \\
\hline Calcium carbonate & a.s. \\
\hline Calcium hydroxide & b.s. \\
\hline Carbon dioxide & a.s. \\
\hline Caprylic acid & a.s. \\
\hline Capric acid & a.s. \\
\hline Carvone & a.s. \\
\hline Cerevisane & a.s. \\
\hline Chitosan hydrochloride & b.s. \\
\hline Clayed charcoal & b.s. \\
\hline COS-OGA & a.s. \\
\hline 1-Decanol & a.s. \\
\hline 1,4-Diaminobutane (aka Putrescine) & a.s. \\
\hline Disodium phosphonate & a.s. \\
\hline Equisetum arvense $\mathrm{L}$. & b.s. \\
\hline Ethylene & a.s. \\
\hline Eugenol & a.s. \\
\hline Extract from Tea tree & a.s. \\
\hline Fatty acids $\mathrm{C} 7-\mathrm{C} 20$ & a.s. \\
\hline Fatty alcohols/aliphatic alcohols & a.s. \\
\hline Fatty acids: Decanoic acid & a.s. \\
\hline Fatty acids: Heptanoic acid & a.s. \\
\hline Fatty acids: Lauric acid & a.s. \\
\hline Fatty acids: Methyl decanoate & a.s. \\
\hline Fatty acids: Octanoic acid & a.s. \\
\hline Fatty acids: Oleic acid incl ethyloleate & a.s. \\
\hline Fatty acids: Pelargonic acid & a.s. \\
\hline Fatty acids: fatty acid methyl ester & a.s. \\
\hline Fenugrec FEN 560 (Fenugreek seed powder) & a.s. \\
\hline Ferric phosphate & a.s. \\
\hline Ferric sulfate & a.s. \\
\hline Fructose & b.s. \\
\hline Garlic extract & a.s. \\
\hline Gibberellin (A4 - A7) & a.s. \\
\hline
\end{tabular}

Table 3 (continued). Approved natural substances under Regulation 1107/2009 - Substances naturelles approuvées par le Règlement 1107/2009.

\begin{tabular}{ll}
\hline Name & Category \\
\hline Heptamaloxyloglucan & a.s. \\
\hline Hydrogen peroxide & b.s. \\
\hline Kieselguhr (aka diatomaceous earth) & a.s. \\
\hline Lactoserum & b.s. \\
\hline Laminarine & a.s. \\
\hline Lecithins & b.s. \\
\hline Lime sulphur & a.s. \\
\hline Limestone & a.s. \\
\hline Maltodextrin & a.s. \\
\hline Mustard seeds powder & b.s. \\
\hline Onion oil & b.s. \\
\hline Orange oil & a.s. \\
\hline Pepper dust extraction residue (PDER) & a.s. \\
\hline Plant oils / Citronella oil & a.s. \\
\hline Plant oils / Clove oil & a.s. \\
\hline Plant oils / Rapeseed oil & a.s. \\
\hline Plant oils / Spear mint oil & a.s. \\
\hline Paraffin oil (various CAS) & a.s. \\
\hline Potassium hydrogen carbonate & a.s. \\
\hline Porstong
\end{tabular}

Potassium phosphonate (formerly potassium a.s. phosphite)

Quartz sand a.s.

Repellents by smell of animal or plant origin/ a.s. fish oil

\begin{tabular}{ll} 
Repellants: Sheep fat & a.s. \\
Rescalure & a.s. \\
\hline Salix cortex & b.s. \\
\hline Seaweed extracts & a.s. \\
Sodium aluminium silicate & a.s. \\
\hline Sodium hydrogen carbonate & b.s. \\
\hline Sucrose & b.s. \\
\hline Sulphur & a.s. \\
Sunflower oil & b.s. \\
Talc E553B & b.s. \\
Urtica spp. & b.s. \\
Vinegar & b.s. \\
Whey & b.s. \\
\hline
\end{tabular}

a.s.: active substance - substance active; b.s.: basic substance - substance basique. 
low molecular weight salts (e.g. ammonium acetate, sodium chloride, acetic acid, and hydrogen peroxide). The interest in this substance list is that their use in plant protection does not require any residue analysis in corresponding crop production. Although these substances are subjected to specific uses, doses and applications defined by the GAP (Good Agricultural Practice) Table, the matching crop production will not need to survey for residues. These features are advantageous not only to the crop production and the food industry, but also for the consumer.

\subsection{Distribution of the substances}

Table contents (categories and types) were converted into figures $\mathbf{1}$ and $\mathbf{2}$. Three-quarters of these substances without MRL are regular active substances with market authorisation (Figure 1). The proportion of basic substances in these tables has been increasing since 2014 and now account for almost $17 \%$ of the total substances despite their low percentage $(4 \%)$ of the total of approved active substances (20/489). Similarly, low-risk substances (a.s. with specific criteria) have seen their proportion in these tables increasing up to $10 \%$.

Natural substances account for $62 \%$ of the tabulated substances and microorganisms represent $36 \%$ of them (Figure 2). The low occurrence of semiochemicals found in table 2 is due to the recent assignment of the MRLs of many of them to Annex V of Implementing

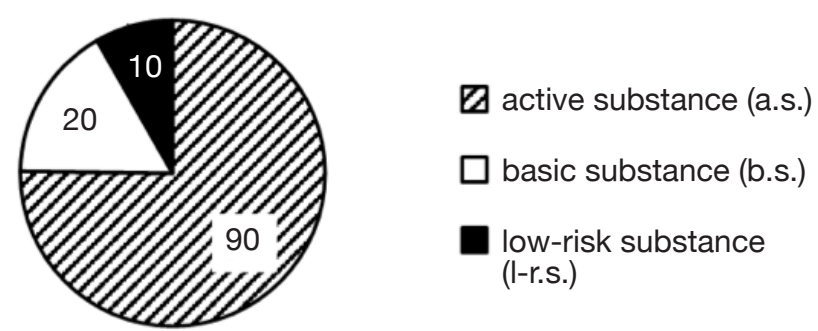

Figure 1. Distribution of substances with no maximum residue limit (MRL) (by type) - Distribution de substances sans limite maximale de résidu (LMR) (par type).

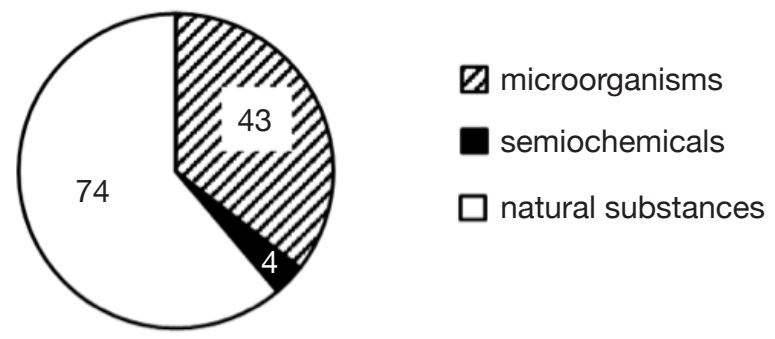

Figure 2. Distribution of substances with no MRL (by BCA category) - Distribution de substances sans limite maximale de résidu (LMR) (par catégorie de BCA).
Regulation (EC) No 396/2005. These, and especially Straight Chain Lepidopteran Pheromones (SCLP) will need to be carefully monitored in the future.

\subsection{Impact on plant protection}

Increasing numbers of labels, licences and certificates raise the question of the absence of pesticide residues to ensure the "guarantee of no residue". In fact, some new certification schemes for vegetable production claiming "without pesticide residue" have been launched in France and in Europe. This certification may require analysis of substances below the MRLs or even below the current Limit Of Detection (LOD), to increase safety for consumers (Czaja et al., 2015). These directions may improve the perception of plant protection products by civil society; estimated as "necessary" by farmers, crop producers and storage parties, some of which are of restricted use or have been withdrawn due to persistent detection in crop and food products (Marchand et al., 2017c). However, up until now the requirements of these labels were not at such a level and in reality, residues guarantees are only set up at the Limit Of Quantification (LOQ) level. Thus, the use of the list of pesticides extracted from our work or concept may be of importance to meet these expectations and claims in an easy way.

The agricultural sectors which seem the most eligible to use this type of substances are greenhouse cultivation and perennial crops. Controlled conditions facilitate the use of these solutions in greenhouses, while perennial crops generally require a greater balance of biodiversity to be preserved. All agricultural sectors are possibly associated with the usage of the substances with no MRL without notable disparities between the sectors.

Currently, changes in crop protection practices involve the substitution of "traditional" pesticides by substances less harmful to human and environmental health. These substances are living organisms (macroorganisms and microorganisms) or more unstable and less persistent molecules, such as hydrogen peroxide. These substances are frequently without MLR, due to their biological nature or their rapid degradation.

\subsection{Evolutions}

Microorganisms are a class of biocontrol agents (Robin \& Marchand, 2018) more likely to be licenced with no MRL. Indeed, recently, the whole group (34 active substances) of Straight Chain Lepidopteran Pheromones (SCLP) was a candidate for inclusion in Annex IV. Again, the potential classification of baculovirus as biocontrol crop protection agents directly acceptable as low-risk substances (EU, 2017) 
may also be a way to amplify the contents of table 2 . Moreover, the possible amplification of the list of low-risk substances by the recent Commission Notice No 2018/C 265/02 (EU, 2018b), clarifying the potential low-risk status, may increase the number of candidates for inclusion in Annex IV.

\section{CONCLUSIONS}

All hundred and twenty active substances have been granted with no Maximum Residue Limits (Tables 1, 2, and 3), but they represent only a few categories of substances; most (90\%) being biocontrol microorganisms and natural substances and mainly (3/4) active substances. The means to find them in databases and legal regulations are described in this paper. Therefore, the usage of these substances and the corresponding plant protection products with Market Authorizations (when compulsory) are to be privileged when possible. Thus, Directive No 2009/128/EC (EC, 2009b) "establishing a framework for Community action to achieve the sustainable use of pesticides" describes, in Article 4 under integrated pest management (IPM), the management of residues. Supervision of crop protection under the "low" or "no residue" goal or label will also be attracted by these listed plant protection implements in our tables, with no residues as found in Annex IV of Regulation No 396/2005. Moreover, this concept should be easier to promote with the probable increase in the global number of substances with no MRLs that are likely to be granted. Indeed, an increase of the number of basic and low-risk substances is expected, together with a regular increase in the number of biocontrol agents (EU, 2018b; Robin \& Marchand, 2018). However, a broader usage of these biocontrol agents involves some dramatic changes in plant protection approach and specific training for producers. Again, the recent growth of "no residue" labels may legitimise this work and the maintenance of the corresponding derivative tables necessary to be updated in the near future.

\section{List of abbreviations}

a.s.: active substance

BCA: biocontrol agents

b.s.: basic substance

1-r.s.: low-risk substance

MRL: maximum residue limits

\section{Bibliography}

Czaja K. et al., 2015. Biopesticides - towards increased consumer safety in the European Union. Pest Manage. Sci., 71(1), 3-6.
De Brabander H.F., Vanden Bussche J., Verbeke W. \& Vanhaecke L., 2011. The economics of residue analysis. Trends Anal. Chem., 30(7), 1088-1094.

DGSanté, 2015. SANCO/11188/2013-rev. 2 of 14.9.2015. Guidance document on criteria for the inclusion of active substances into Annex IV of Regulation (EC) No 396/2005, https://ec.europa.eu/food/sites/ food/files/plant/docs/pesticides_mrl_guidelines_ sanco-2013-11188.pdf, (April 12, 2018).

DGSanté, 2017a. EU Pesticides database, http://ec.europa. eu/food/plant/pesticides/eu-pesticides-database/ public/?event=activesubstance. .selection\&language $=\mathrm{EN}$ then select "advanced search" and later select "type" "basic substances", (April 12, 2018).

DGSanté, 2017b. EU Pesticides database, http://ec europa. eu/food/plant/pesticides/eu-pesticides-database/ public/?event=activesubstance. .selection\&language $=\mathrm{EN}$ then select "advanced search" and later select "type" "low-risk substances", (April 12, 2018).

DGSanté, 2017c. EU Pesticides database, http://ec.europa. eu/food/plant/pesticides/eu-pesticides-database/ public/?event=download.MRL, (April 12, 2018).

EC, 2005. Commission Regulation (EC) No 396/2005. Off. J. Eur. Union, L 70, 16.3.2005, 1-16.

EC, 2009a. Commission Regulation (EC) No 1107/2009 of the European Parliament and the Council of 21 October 2009 concerning the placing of plant protection products on the market and repealing Council Directives 79/117/ EEC and 91/414/EEC. Off. J. Eur. Union, L 309, 1-50.

EC, 2009b. Directive 2009/128/EC of the European Parliament and of the Council of 21 October 2009 establishing a framework for Community action to achieve the sustainable use of pesticides. Off. J. Eur. Union, L 309, 24.11.2009, 71-86.

EU, 2011. Commission implementing Regulation No 540/2011. Off. J. Eur. Union, L 153, 11.6.2011, 1-186.

EU, 2017. Commission implementing Regulation (EU) No 2017/1432 amending Regulation (EC) No 1107/2009 of the European Parliament and the Council concerning the placing of plant protection products on the market as regards the criteria for the approval of low-risk active substances. Off. J. Eur. Union, L 205, 8.8.2017, 59-32.

EU, 2018a. Commission Regulation (EU) No 2018/62 of 17 January 2018 replacing Annex I to Regulation (EC) No 396/2005 of the European Parliament and of the Council. Off. J. Eur. Union, L 18, 23.1.2018, 1-73.

EU, 2018b. Commission Notice concerning a list of potentially low-risk active substances approved for use in plant protection (2018/C 265/02). Off. J. Eur. Union, C 265, 27.7.2018, 8-11.

Fleming C.R. et al., 2017. Comprehensive analysis of the value of single versus multiple year (season) crop residue data for establishment of maximum residue levels (MRLs). J. Agric. Food Chem., 65(8), 17841791. 
Marchand P.A., 2015. Basic substances: an opportunity for approval of low-concern substances under EU pesticide regulation. Pest Manage. Sci., 71(9), 1197-1200.

Marchand P.A., 2016. Basic substances under EC 1107/2009 phytochemical regulation: experience with non-biocide and food products as biorationals. J. Plant Prot. Res., 56(3), 271-277.

Marchand P.A., 2017a. Basic substances under EU Pesticide Regulation: an opportunity for organic production? Org. Farming, 3(1), 16-19.

Marchand P.A., 2017b. Basic and low risk substances under EU pesticide regulation: a new choice for biorationals portfolio of small and medium-sized enterprises. J.Plant Prot.Res., 57(4), 434-440.

Marchand P.A., Dimier-Valet C. \& Vidal R., 2017c. Biorational substitution of piperonyl butoxide in organic production: effectiveness of vegetable oils as synergists for pyrethrums. Environ. Sci. Poll. Res., 25(30), 1-7.

Marchand P.A., 2018. Novel plant protection regulation: new perspectives for organic production? Org. Farming, 4(1), 3-6.

Pedersen B. et al., 2016. Protecting our food: can standard food safety analysis detect adulteration of food products with selected chemical agents? Trends Anal. Chem., 85(B), 42-46.

Robin D.C. \& Marchand P.A., 2018. Biocontrol active substances: evolution since the entry in vigour of
Reg. 1107/2009. Pest Manage. Sci., doi.org/10.1002/ ps.5199

Robin D.C. \& Marchand P.A., 2019. Low-risk substances, new effective category of biocontrol agents as lever for durable crop protection products. Chron. Bioresour. Manage., accepted.

Romero-González R., 2015. Food safety: how analytical chemists ensure it. Anal. Methods, 7, 7193-7201.

Villaverde J.J. et al., 2016. Trends in analysis of pesticide residues to fulfil the European Regulation (EC) No. 1107/2009. Trends Anal. Chem., 80, 568-580.

Xiong B. \& Beghin J., 2014. Disentangling demandenhancing and trade-cost effects of maximum residue regulations. Econ. Inq., 52, 1190-1203.

Yamada Y., 2017. Chapter 7. Importance of codex maximum residue limits for pesticides for the health of consumers and international trade. In: Ambrus A. \& Hamilton D., eds. Food safety assessment pesticide residues. World Scientific, 269-282.

Yeung M. et al., 2017. Why maximum residue limits for pesticides are an important international issue. In: Yeung M. et al. Declining international cooperation on pesticide regulation. Springer, 1-9.

(28 ref.) 